\title{
Chloramphenicol Acetylation in Streptomyces
}

\author{
By W. V. SHAW \\ Department of Biochemistry, University of Leicester, Leicester LEI $7 R H$ \\ AND D. A. HOPWOOD \\ John Innes Institute, Colney Lane, Norwich $\mathrm{NR}_{4}{ }_{7} \mathrm{UH}$
}

(Received II September 1975; revised 8.November 1975)

SUMMARY

\begin{abstract}
Twenty-one strains of actinomycetes were screened for the presence of chloramphenicol acetyltransferase, the enzyme responsible for chloramphenicol resistance in many species of bacteria. Only five strains, belonging to three species, yielded mycelial lysates which catalysed the formation of chloramphenicol acetates in the presence of acetyl-coenzyme A: Streptomyces coelicolor Müller, S. acrimycini, and $S$. griseus. A mutant of $S$. acrimycini selected for an increase in resistance to chloramphenicol had a higher specific activity for chloramphenicol acetyltransferase than that found in the parental strain; the enzyme was not inducible in the mutant, the parental strain, or any other strain tested. Chloramphenicol was not acetylated by lysates of a strain of $S$. venezuelae, the organism known to produce it.
\end{abstract}

\section{INTRODUCTION}

Chloramphenicol resistance in numerous species of bacteria is associated with inactivation of the antibiotic by enzymic acetylation (Shaw, 1974). The presence of the enzyme responsible for the resistant phenotype, chloramphenicol acetyltransferase, was originally noted in isolates of Escherichia coli and related enteric bacteria which carried R factors (Shaw, 1967; Suzuki \& Okamoto, 1967) and in staphylococci harbouring plasmids for chloramphenicol resistance (Shaw \& Brodsky, 1968). More recently, the acetylating enzyme has been described in Proteus spp., Agrobacterium tumefaciens, Streptococcus faecalis, Diplococcus pneumoniae (reviewed by Shaw, 1974), and Myxococcus spp. (Burchard \& Parish, 1975).

In most cases examined it has been easier to ascribe the mechanism of chloramphenicol resistance to enzymic acetylation than rigorously to define its genetic determination. Circumstantial evidence for plasmid linkage has been found for the chloramphenicol acetyltransferase gene in some of the organisms noted above.

The notion that the commonly found plasmid-linked genes for the acetylating enzymes may have arisen by mobilization of a chromosomal precursor in Proteus or some other species has been an attractive one. The observation of Argoudelis \& Coats (1971) that a member of the genus Streptomyces was capable of acetylating chloramphenicol suggested that a survey of other members of the genus might be informative. Organisms potentially capable of antibiotic synthesis might, a priori, be expected to carry out antibiotic-specific enzyme transformations, a point emphasized by Benveniste \& Davies (1973). The present study was designed to examine a number of species of actinomycetes for the presence of chloramphenicol acetyltransferase, to correlate their rates of acetylation with their sensitivity to chloramphenicol, and to acquire preliminary information on the nature of the enzyme in actinomycetes. 
Table I. Actinomycete strains tested for chloramphenicol acetylation by the chromatographic method

John Innes stock no.

104

2159

I 57

I 201

1326

1472

1459

2246

2248

2207

2209

2210

2155

2222

2204

2211

2212

I 158

1159

II95

1276

\section{Description}

Streptomyces coelicolor *

$S$. coelicolor Müller*

$S$. coelicolor Müller*

S. acrimycini

S. lividans

S. glaucescens

S. rimosus

S. rimosus

$S$. rimosus

$S$. roseochromogenes

$S$. viridochromogenes

$S$. viridochromogenes

$S$. venezuelae

S. venezuelae var. spiralis

$S$. erythrochromogenes

S. griseus

S. griseus

Streptomyces sp. (unidentified)

Streptomyces sp. (unidentified)

Streptomyces sp. (unidentified)

Nocardia mediterranei
Origin/remarks

his, str-R, SCPI ${ }^{+}$derivative of A3(2)
UC5240 of Argoudelis \& Coats (I97I)
Kutzner I I 22
IPVI6IO
66 of Lomovskaya et al. (1972)
ETH22794
NRRL2234
I8274 of Pfizer Ltd., Sandwich, Kent
CUB520
CUB530
CUB539 (ATCCI4920)
At-40 (Okanishi)
CUB528
CUB486
CUB609
CUB625
$\quad$.
ATCCI3685

Chloramphenicol acetylation

$$
\begin{gathered}
- \\
++ \\
++ \\
+++ \\
= \\
= \\
- \\
- \\
= \\
= \\
= \\
- \\
+ \\
++ \\
= \\
-
\end{gathered}
$$

* Kutzner \& Waksman (1959) found that strains earlier classified as $S$. coelicolor fell into two classes and proposed a reclassification of one class as $S$. violaceoruber; II 57 and 2159 are strains for which the name $S$. coelicolor was retained, while A3(2), represented here by its derivative 104, is a strain of the $S$. violaceoruber type. Strain A3(2) has been extensively studied genetically (Hopwood, et al., I973).

cub, Collection of the University of Bradford (T. Cross); ETH, Eidgenössische Technische Hochschule, Zurich; IPV, Istituto Patologia Vegetale, Milan. AT, Department of Antibiotics, National Institute of Health, Tokyo.

\section{METHODS}

Organisms and media. The strains of actinomycetes screened for the presence of chloramphenicol acetyltransferase are listed in Table $\mathrm{r}$. For the preparation of extracts, organisms were grown by the inoculation of spore suspensions into 200 or $500 \mathrm{ml}$ of the following liquid medium in $2000 \mathrm{ml}$ Erlenmeyer flasks, followed by orbital shaking at $30{ }^{\circ} \mathrm{C}$ for 40 to $48 \mathrm{~h}$. The medium contained $\left(\mathrm{g}^{-1}\right)$ : Difco Casamino acids, 24; glycine, 5; glucose, 5; $\mathrm{MgCl}_{2}, 10 \cdot 25$. Vitamins were included by the addition of $\mathrm{I} \mathrm{ml}$ of a stock solution containing $(\mathrm{g} / 100 \mathrm{ml})$ : riboflavine, $\mathrm{O} . \mathrm{I}$; nicotinamide, $\mathrm{O} . \mathrm{I} ; p$-aminobenzoic acid, $0.0 \mathrm{I}$; pyridoxine- $\mathrm{HCl}$, 0.05 ; thiamine- $\mathrm{HCl}, 0.05$; biotin, 0.02 . The major components of the medium were chosen to facilitate subsequent lysis of the mycelium by lysozyme; vitamins were probably unimportant for the purposes of the present study.

Preparation of cell-free extracts. The mycelium was collected by centrifugation, washed with $0.05 \mathrm{M}$-Tris- $\mathrm{HCl}, \mathrm{pH} 7 \cdot 6$, and resuspended in 5 to $10 \mathrm{ml}$ of the same buffer. Lysozyme was added at a final concentration of $2.5 \mathrm{mg} \mathrm{ml}^{-1}$ and the suspension incubated at $30{ }^{\circ} \mathrm{C}$ for 30 to $60 \mathrm{~min}$, depending on the strain and rapidity of lysis. Approximately 5 to $10 \mu \mathrm{g}$ of deoxyribonuclease were added and, after incubating for several more minutes, the preparation was sonicated briefly and frozen. After thawing, each 5 to $10 \mathrm{ml}$ of culture extract was clarified by centrifugation at $18000 \mathrm{~g}$ for $30 \mathrm{~min}$, after which the supernatant was taken for dialysis against $\mathrm{I} 1$ of $0.02 \mathrm{M}-\mathrm{Tris}-\mathrm{HCl}, \mathrm{pH} 7.8$ at $4{ }^{\circ} \mathrm{C}$ for $\mathrm{I} 6 \mathrm{~h}$. Protein was determined by the method of Lowry et al. (I95I). 
Assay of chloramphenicol acetyltransferase. Acetylation of chloramphenicol was detected chromatographically following the incubation of dialysed cell-free extracts with $\left[{ }^{14} \mathrm{C}\right]-$ chloramphenicol and acetyl-CoA as described by Shaw (1975). For the present experiments the incubation mixtures contained the following, at the final concentrations indicated, in a total volume of $0.15 \mathrm{ml}$ : crude extract (protein), I 30 to $330 \mu \mathrm{g} \mathrm{ml}^{-1}$; acetyl-CoA, I mM; $\left[{ }^{14} \mathrm{C}\right]$ chloramphenicol (The Radiochemical Centre, Amersham, Buckinghamshire; specific activity $8.8 \mathrm{mCi} / \mathrm{mmol}$ ), $0 . \mathrm{I} \mathrm{mM}$; Tris- $\mathrm{HCl}$ buffer, $\mathrm{pH} 7.8,50 \mathrm{mM}$. After 20 min at $37^{\circ} \mathrm{C}$, the assay mixture was extracted twice with $\mathrm{I} \mathrm{ml}$ ethyl acetate, the extracts were pooled and dried, and the samples were then taken up in a few drops of $95 \%(\mathrm{v} / \mathrm{v})$ ethanol and spotted at the origin of silica gel thin-layer sheets for ascending chromatography in chloroform-methanol $(97 \cdot 5: 2 \cdot 5, \mathrm{v} / \mathrm{v})$. Autoradiographs were used to locate the radioactive substrate and products. Quantification of enzyme activity was achieved by cutting out the chromatogram areas containing radioactive substrate and product and placing them directly in scintillation vials for counting. The specific activity of chloramphenicol acetyltransferase was then determined from a knowledge of the total radioactivity and concentration of chloramphenicol present in the incubation, the fraction of $\left[{ }^{14} \mathrm{C}\right]$ chloramphenicol converted to the 3 -acetate, and the protein concentration of the extract.

Each experiment with one or more strains of actinomycetes was accompanied by parallel incubations containing either no culture lysate or a cell-free extract of $E$. coli strain KI2 carrying R factor 222 (same as Rıo0; see Nisioka, Mitani \& Clowes, 1970) which mediates the synthesis of chloramphenicol acetyltransferase. The occurrence of chloramphenicol acetylation was scored by comparison of the autoradiographs of each actinomycete incubation with the appropriate controls. Culture lysates showing evidence compatible with chloramphenicol acetylation were retested by examination of the specificity of the reaction as described by Shaw (1975). Since chloramphenicol acetyltransferase is specific for the biologically active $\mathrm{D}$-threo isomer of the antibiotic, each presumptive positive was checked by incubating the lysate in question with $\left[{ }^{14} \mathrm{C}\right]$ acetyl-CoA and non-radioactive chloramphenicol of either the D-threo or L-erythro configuration. All such incubations yielded autoradiographs showing acetylation of only the D-threo stereoisomer. Because of the low level of chloramphenicol acetyltransferase activity in the streptomyces species examined, it was not possible to use the more convenient spectrophotometric assay for the enzyme (Shaw, 1975) when crude wild-type culture lysates were examined. The latter method was used only for the measurement of chloramphenicol acetylation in a mutant with an increased level of activity (see Results). The correlation between the results of the radioactive chromatographic assay and those obtained with the spectrophotometric procedure was excellent.

Determination of chloramphenicol resistance. A glucose-asparagine minimal medium (Hopwood, 1967) in liquid or agar gel form and supplemented with growth factors was used for the determination of antibiotic resistance. L-Arginine, L-cysteine, DL-homoserine, L-leucine, L-phenylalanine and L-proline were added at $500 \mathrm{mg} \mathrm{1}^{-1}$; L-histidine was included at $750 \mathrm{mg} \mathrm{l}^{-1}$. Uracil and adenine were present at $100 \mathrm{mg} \mathrm{l}^{-1}$ and nicotinamide was present at $7 \mathrm{mg} \mathrm{1}^{-1}$. Spore suspensions were inoculated into liquid media or spread on agar plates containing concentrations of chloramphenicol over the range from 5 to $200 \mu \mathrm{g} \mathrm{ml}^{-1}$. After varying periods of incubation at $30^{\circ} \mathrm{C}$,"each culture was compared with controls incubated in the absence of antibiotic. The minimum concentration required for complete inhibition of growth in liquid medium was in each case approximately twice that observed for the same organism on solid medium.

Tests for destruction of chloramphenicol. Spores were inoculated into $30 \mathrm{ml}$ amounts of liquid minimal medium in $250 \mathrm{ml}$ Erlenmeyer flasks with 10 or $15 \mu \mathrm{g}$ chloramphenicol $/ \mathrm{ml}$, 
and incubated at $30{ }^{\circ} \mathrm{C}$ in a shaking water bath. After various periods, $2 \mathrm{ml}$ samples were withdrawn, Millipore filtered and stored at $4{ }^{\circ} \mathrm{C}$. When all samples had been collected, a few drops of a stationary-phase culture of $E$. coli, sensitive to inhibition by chloramphenicol at a concentration of approximately $4 \mu \mathrm{g} \mathrm{ml}^{-1}$, were added. Visible turbidity after incubation at $37^{\circ} \mathrm{C}$ for $8 \mathrm{~h}$ indicated destruction of chloramphenicol.

Attempts to induce increases in chloramphenicol resistance and enzymic acetylation. Samples of spore suspensions were inoculated and incubated with shaking, as described above, in the presence or absence of $15 \mu \mathrm{g}$ chloramphenicol $/ \mathrm{ml}$. After $24 \mathrm{~h}$ incubation the mycelium was centrifuged and samples were plated on agar containing various concentrations of chloramphenicol. Samples were also taken for the preparation of lysates and assay of chloramphenicol acetylation by either the radioactive method (strains 2159 and $120 \mathrm{I}$ ) or the spectrophotometric method (strain 2236).

Selection of a chloramphenicol-resistant mutant of Streptomyces acrimycini. Strain I20I was mutagenized under the conditions described by Delić, Hopwood \& Friend (1970). A spore suspension was incubated for $60 \mathrm{~min}$ at $30{ }^{\circ} \mathrm{C}$ in a solution containing $N$-methyl$N^{\prime}$-nitro- $N$-nitrosoguanidine (NTG) (I mg ml-1) and $0.05 \mathrm{M}$-Tris-maleate buffer, $\mathrm{pH}$ 9. The spores were collected by centrifugation and resuspended in $30 \mathrm{ml}$ of liquid medium in a $250 \mathrm{ml}$ Erlenmeyer flask and incubated at $30^{\circ} \mathrm{C}$ on a gyratory shaker for $9 \mathrm{~h}$ to allow mutation expression. The very young mycelium was centrifuged, resuspended in a small volume of water and samples were spread on plates containing 5, 10, 15 or $20 \mu \mathrm{g}$ chloramphenicol $/ \mathrm{ml}$. After incubation at $30^{\circ} \mathrm{C}$ for several days, near-confluent growth occurred on chloramphenicol concentrations up to $\mathrm{I} 5 \mu \mathrm{g} \mathrm{ml}^{-1}$. There was considerable background growth at $20 \mu \mathrm{g} \mathrm{ml}^{-1}$, but six discrete colonies were recognized on three plates and streaked on a fresh plate containing $20 \mu \mathrm{g}$ chloramphenicol $/ \mathrm{ml}$, together with a control patch of parent strain I20I. After incubation the plate was replica-plated on to solid medium containing 20,40 or $60 \mu \mathrm{g}$ chloramphenicol $/ \mathrm{ml}$. The control patch and five of the possible mutant cultures grew at $20 \mu \mathrm{g} \mathrm{ml}^{-1}$ but not at $40 \mu \mathrm{g} \mathrm{ml}^{-1}$, while one culture (designated 2236) grew at $40 \mu \mathrm{g} \mathrm{ml}^{-1}$ but not at $60 \mu \mathrm{g} \mathrm{ml}^{-1}$. This increased resistance of 2236 compared with I20 I was reproducible. Two attempts were made to increase the resistance of 2236 by a further round of mutagenesis by NTG or by exposure to ultraviolet radiation, but no mutant resistant to higher chloramphenicol concentrations was isolated.

Fig. I. Autoradiographic demonstration of chloramphenicol acetylation by lysates of streptomyces. (a) The formation of radioactive products [chloramphenicol I-acetate (CM-I-Ac), chloramphenicol 3-acetate (CM-3-Ac) and chloramphenicol 1,3-diacetate (CM(Ac) $\left.)_{2}\right)$ formed after the incubation of $\left[{ }^{14} \mathrm{C}\right]$ chloramphenicol $(\mathrm{CM})$ with acetyl-CoA and lysates of the following: (I) $S$. coelicolor Müller (strain 21 59); (2) S. coelicolor A3(2)/(104); (3) S. lividans (1326); (4) S. glaucescens (1472); (5) $S$. acrimycini (I2OI) and (6) $E$. coli KI 2 carrying an R factor 222 conferring chloramphenicol resistance. The formation of chloramphenicol diacetate in (6) was due to the higher specific activity of chloramphenicol acetyltransferase in $\mathrm{R}^{+}$strains of $E$. coli as compared with the two acetyltransferase containing streptomyces strains represented by (I) and (5). (b) The results of an identical experiment using lysates of the following: (7) Nocardia mediterranei (1276); (8) S. rimosus (I459); (9) S. roseochromogenes (2207); (1 o) S. viridochromogenes (2209); (I I) S. viridochromogenes (2210); (12) S. venezuelae (2222); (13) S. erythrochromogenes (2204); (14) S. griseus (2211); (15) S. griseus (2212); (16) $S$. rimosus (2248) and (17) $S$. rimosus (2246). In (b) note the strong positive reaction in (15); all the other reactions were negative except for a very weak positive reaction in (14) revealed only in an over-exposed autoradiograph (not shown). Similar experiments with the three unidentified strains of streptomyces, numbers I I 58, I I 59, I 95 (chromatograms not shown) showed no evidence of chloramphenicol acetylation, while $S$. coelicolor Müller strain 1 I 57 showed a weak acetylation reaction. See Table I for further details of the strains. 

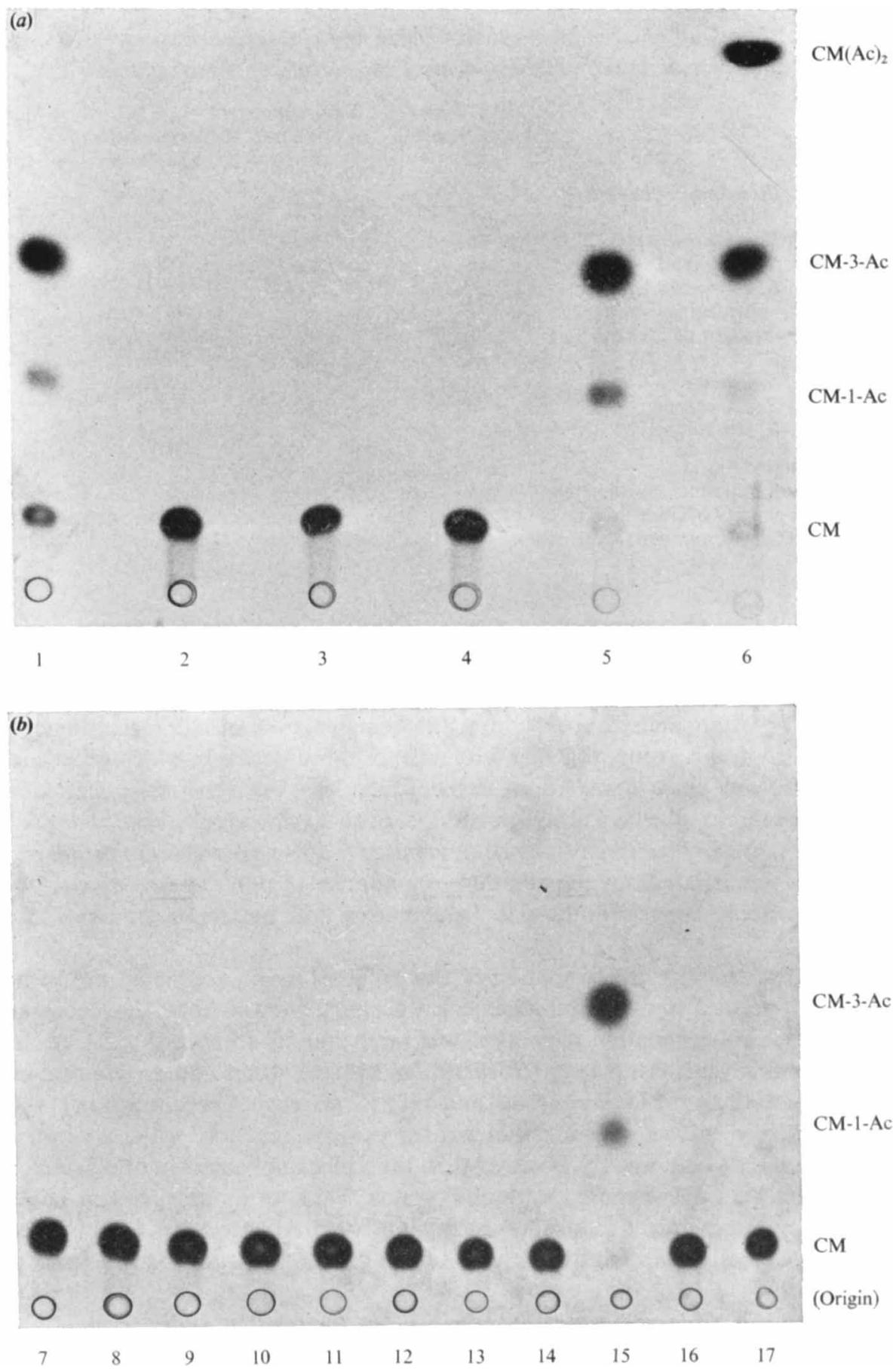

Fig. I $(a)$ and $(b)$. For legend see facing page. 
Table 2. Levels of chloramphenicol resistance and chloramphenicol acetyltransferase in, and destruction of chloramphenicol by, certain of the strains in Table I

\begin{tabular}{|c|c|c|c|c|c|}
\hline $\begin{array}{l}\text { John Innes } \\
\text { stock no. }\end{array}$ & Strain & $\begin{array}{c}\text { M.i.c.* for } \\
\text { chloramphenicol } \\
(\mu \mathrm{g} / \mathrm{ml})\end{array}$ & $\begin{array}{c}\text { Destruction } \\
\text { of antibiotic } \\
\text { activity }\end{array}$ & $\begin{array}{l}\text { Chloramphenicol } \\
\text { acetylation }\end{array}$ & $\begin{array}{l}\text { Chloramphenicol } \\
\text { acetyl- } \\
\text { transferase } f\end{array}$ \\
\hline 2159 & $\begin{array}{l}\text { Streptomyces coelicolor } \\
\text { Müller }\end{array}$ & 5 & Yes & Yes & 0.6 \\
\hline 104 & S. coelicolor $\mathrm{A} 3(2)$ & 20 & No & No & - \\
\hline 1201 & S. acrimycini & 10 & Yes & Yes & $I \cdot 0$ \\
\hline 2236 & $\begin{array}{l}\text { S. acrimycini (chloram- } \\
\text { phenicol-resistant } \\
\text { mutant of } 1201 \text { ) }\end{array}$ & 40 & Yes & Yes & $32 \cdot 0$ \\
\hline 2212 & S. griseus & NT & NT & Yes & 0.8 \\
\hline 1326 & S. lividans & 10 & NT & No & - \\
\hline 1472 & S. glaucescens & IO & NT & No & 一 \\
\hline 2155 & $S$. venezuelae & $>100,<200$ & NT & No & - \\
\hline
\end{tabular}

\section{RESULTS}

\section{Occurrence of the chloramphenicol acetylation phenotype}

The strains of actinomycetes tested for evidence of chloramphenicol acetylation, and the results, are listed in Table I. The strain 2159 of Streptomyces coelicolor Müller originally described by Argoudelis \& Coats (197I) as being capable of chloramphenicol acetylation was included in this group, together with most of those strains in which genetic studies have been carried out, since it was hoped to identify at least one genetically characterized strain possessing chloramphenicol acetyltransferase. Such strains were $S$. coelicolor A3(2)/(I04), $S$. lividans (1326), S. glaucescens (1472), S. rimosus (1459) and Nocardia mediterranei (1276). The group was enlarged by the addition of a number of other strains chosen by essentially arbitrary criteria. See the footnote to Table I for a note on the taxonomy of ' $S$. coelicolor' strains.

Qualitative tests for the formation of the expected mono-acetylated products, chloramphenicol 3-acetate and chloramphenicol I-acetate, showed that the occurrence of the chloramphenicol acetylation phenotype was rarer than its absence (Fig. I). A clear positive reaction was given by the 2159 (S. coelicolor Müller) strain and an approximately equal activity by strains I 20 I (S. acrimycini) and 2212 (S. griseus). A second strain (I I 57) classified as $S$. coelicolor Müller gave a rather weaker positive reaction, while a second $S$. griseus strain (221I) was so weakly positive that the chloramphenicol mono-acetates could be detected only on over-exposed autoradiographs. Thus, of 2 I independent natural isolates of actinomycetes, only five strains, belonging to three species, were found to acetylate chloramphenicol. Disappointingly, none of the genetically studied strains was positive.

\section{Chloramphenicol inactivation and the resistance phenotype}

The data in Table 2 suggest that the presence of the acetylating enzyme is not the only factor contributing to the level of sensitivity of streptomyces strains to chloramphenicol. A case in point is Streptomyces venezuelae, the chloramphenicol-producing organism, which, although resistant or indifferent to a concentration in excess of $100 \mu \mathrm{g} \mathrm{ml}^{-1}$, showed no evidence of acetylation. However, the three species shown to inactivate chloramphenicol 
contained chloramphenicol acetyltransferase in their mycelial lysates. Selection for an isolate of $S$. acrimycini with increased resistance to chloramphenicol (approximately 2- to 4-fold) yielded strain 2236 which had an enzyme specific activity more than $30-$ fold higher than that of the parental organism (strain I20I).

Tests for enzyme induction were made with $S$. coelicolor Müller (strain 2159) and with both the parent (strain I20I) and chloramphenicol-resistant mutant (strain 2236) of $S$. acrimycini. The level of enzyme in mycelial lysates was not found to be influenced by the presence of chloramphenicol at the time of inoculation or by further additions of the antibiotic during growth or immediately before harvest (secondary additions tested only in $S$. acrimycini). Streptomyces coelicolor Müller (strain 2159) was also examined for evidence of induction of an increased expression of resistance to chloramphenicol following exposure to the antibiotic. The minimal inhibitory concentration for chloramphenicol in agar was the same for mycelium grown from medium containing $15 \mu \mathrm{g}$ antibiotic/ml as it was for that obtained after growth in the absence of the drug.

\section{DISCUSSION}

The findings of the present study confirm the report of Argoudelis \& Coats (1971) that $S$. coelicolor Müller is capable of acetylating chloramphenicol. The earlier study was performed with growing cultures, and the products included the 3-propionyl and 3-butyryl (or iso-butyryl) esters of chloramphenicol in addition to the predominant I-acetyl and 3acetyl derivatives. Similar results were obtained in the present investigation when undialysed extracts of $S$. coelicolor Müller, $S$. acrimycini, and $S$. griseus were tested for acetylation activity using $\left[{ }^{14} \mathrm{C}\right]$ chloramphenicol and acetyl-CoA with the chromatographic assay. Autoradiographs of the products revealed not only the expected acetate esters but also small amounts of three radioactive products with the chromatographic properties of the propionyl and butyryl mono-esters and the di-propionyl ester of chloramphenicol. Taken together with earlier studies on chloramphenicol acetylation in $E$. coli (Shaw, 1975), it seems likely that the acetyltransferase activity of streptomyces strains is not specific for the acetyl thioester of CoA and that crude undialysed extracts contain both the necessary short-chain fatty acids and a transesterification system to synthesize the propionyl- and butyryl-CoA.

Only five of $2 \mathrm{I}$ isolates of actinomycetes tested were capable of enzymic chloramphenicol acetylation. This finding is compatible with the notion that the acetylation phenotype is mediated by a plasmid-linked gene, although a chromosomal location is by no means excluded. Further studies are needed on this point, including a correlation of the acetylation phenotype with the presence or absence of plasmid DNA. The isolation of a $S$. acrimycini mutant (strain 2236) which has an increased level of both chloramphenicol resistance and acetylating activity compared with the parental strain I20I should be a useful step towards such studies.

Since the genes for enzymes which inactivate chloramphenicol and the aminoglycoside family of antibiotics are extra-chromosomal in naturally-occurring isolates of enteric bacteria and staphylococci, there has been a tendency to look to other genera for their possible origin. Benveniste \& Davies (1973) called attention to the ubiquity of aminoglycoside-inactivating enzymes in actinomycetes and pointed out that these enzymes have certain properties in common with those which are plasmid-mediated in clinically-important organisms. The streptomycin phosphorylating enzyme in the producing organism $S$. griseus (Walker \& Skorvaga, 1973) might suggest that antibiotic-modifying enzymes specific for the synthesized antibiotic would be generally present in the producing species. The absence of 
evidence for chloramphenicol acetylation in $S$. venezuelae, which is highly resistant to its antibiotic product, suggests that there may be no general rule and that $S$. venezuelae may use an alternative mechanism to circumvent auto-inhibition. Experiments reviewed by Vining, Malik \& Westlake ( 1968 ) suggest that $S$. venezuelae is indeed capable of modifying chloramphenicol, but it is by no means clear that enzymic inactivation is the sole mechanism preventing the inhibition of host ribosomal protein synthesis by chloramphenicol.

Current efforts are being directed at a characterization of the purified enzyme from $S$. acrimycini to compare it with variants found in other genera, and studies are also in progress to define the genetic determination of the acetylation phenotype.

We gratefully acknowledge the skilled assistance of Mrs Helen M. Wright and Mrs Diana Doran.

\section{REFERENCES}

ARgoudelis, A. D. \& CoATS, J. H. (I97I). Microbial transformation of antibiotics. VI. Acylation of chloramphenicol by Streptomyces coelicolor. Journal of Antibiotics 24, 206-208.

Benveniste, R. \& Davies, J. (1973). Aminoglycoside antibiotic-inactivating enzymes in Actinomycetes similar to those present in clinical isolates of antibiotic-resistant bacteria. Proceedings of the National Academy of Sciences of the United States of America 70, 2276-2280.

Burchard, R. P. \& Parish, J. H. (1975). Chloramphenicol resistance in Myxococcus xanthus. Antimicrobial Agents and Chemotherapy 7, 233-238.

Delić, V., Hopwood, D. A. \& FrIEND, E. J. (1970). Mutagenesis by $N$-methyl- $N$ '-nitro- $N$-nitrosoguanidine (NTG) in Streptomyces coelicolor. Mutation Research 9, 167-192.

Hopwood, D. A. (1967). Genetic analysis and genome structure in Streptomyces coelicolor. Bacteriological Reviews 3r, 373-403.

Hopwood, D. A., Chater, K. F., Dowding, J. E. \& Vivian, A. (1973). Advances in Streptomyces coelicolor genetics. Bacteriological Reviews 37, 37I-405.

KutzNer, H. J. \& Waksman, S. A. (1959). Streptomyces coelicolor Müller and Streptomyces violaceoruber Waksman and Curtis, two distinctly different organisms. Journal of Bacteriology 78, 528-538.

Lomovskaya, N. D., Mkrtumian, N. M., Gostimskaya, N. L. \& Danilenko, V. N. (1972). Characterization of temperature actinophage $\phi \mathrm{C}_{3} \mathrm{I}$ isolated from Streptomyces coelicolor A3(2). Journal of Virology 9, $25^{8-262 .}$

Lowry, O. H., Rosebrough, N. J., Farr, A. L. \& Randall, R. J. (195I). Protein measurement with the Folin phenol reagent. Journal of Biological Chemistry 193, 265-275.

Nisioka, T., Mitani, M. \& Clowes, R. C. (I970). Molecular recombination between R factor deoxyribonucleic acid molecules in Escherichia coli host cells. Journal of Bacteriology ro3, $166-177$.

SHAw, W. V. (1967). The enzymatic acetylation of chloramphenicol by extracts of $\mathrm{R}$ factor resistant Escherichia coli. Journal of Biological Chemistry 242, 687-693.

SHAw, W. V. (1974). Genetics and enzymology of chloramphenicol resistance. Biochemical Society Transactions 2, 834-838.

SHAW, W. V. (1975). Chloramphenicol acetyltransferase from chloramphenicol-resistant bacteria. In Methods in Enzymology, vol. 43, pp. 737-755. Edited by J. H. Hash. New York: Academic Press.

SHAw, W. V. \& BRodsky, R. F. (I968). Characterization of chloramphenicol acetyltransferase from chloramphenicol-resistant Staphylococcus aureus. Journal of Bacteriology 95, 28-36.

Suzuki, Y. \& Oкамото, S. (1967). The enzymatic acetylation of chloramphenicol by the multiple drug resistant Escherichia coli. Journal of Biological Chemistry 242, 4722-4730.

Vining, L. C., Malik, V. S. \& Westlake, D. W. S. (1968). Biosynthesis of chloramphenicol. Lloydia 31, $355-363$.

WAlKer, J. B. \& Skorvaga, M. (1973). Phosphorylation of streptomycin and dihydrostreptomycin by Streptomyces. Journal of Biological Chemistry 248, 2435-2440. 